\title{
ALEX-TRONIX
}

\section{AUTOMATIC CONTROLLERS}

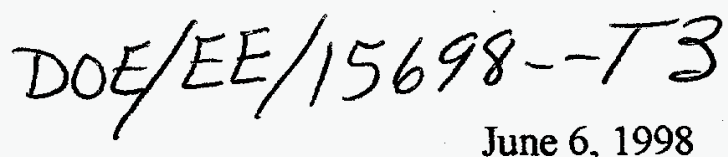

June 6, 1998

Mr. Fred L. Hart

U.S Department of Energy, EE-52

Mails Stop 5E-052

1000 Independence Ave, SW

Washington, DC 20585-0121

Dear Mr Hart:

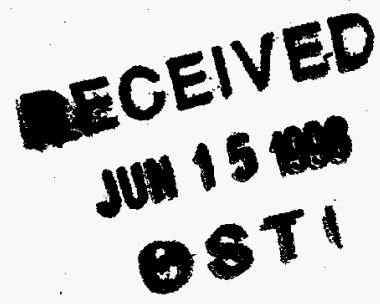

Re: Grant \#DE-FG01-97EE15698: third quarterly report

I am continuing to explore three methods of marketing the solenoid power saving device.

Since the redesign reported in the last report, we are pursuing both the OEM market, the distributor market in both turf and agricultural areas, and the export market. Progress in these areas is as follows:

OEM:

We have supplied Toro 10 units of the Swell adapted to their valve in head sprinkler for evaluation. Their laboratory tests confirmed the electrical energy conservation characteristics we claimed. At last report, they have installed 10 units in the field for about 30 days and are conducting field tests. To date no report of their field tests have been received, but it is believed that 60 to 90 days will be required for effective evaluation.

I am considering approaching Toro's main competitor which is Rain Bird as a second OEM. Buckner Sprinklers is another possible OEM for this product, especially since I have negotiated the use of the Buckner solenoid with my standard Swell. Buckner needed a molded plastic box for one of their irrigation controllers, which I agreed to supply to them at my cost, in return, they will be supplying me their new solenoid at their cost. In effect, I can purchase solenoids in 1000 lots for the same price they are paying for 50-100,000 pieces.

\section{DISTRIBUTION:}

The marketing consultant I hired about 3 months ago has contacted a number of turf architects and designers. We believe that getting the product specified by these designers will facilitate their introduction to distributors. In addition, we have contacted several of the CalTrans field offices which take care of the highway landscape and irrigation for their endorsement and use. There has been very good response to the product. We have supplied them with a small number of samples. They have requested additional samples for evaluation. The holdup in supplying them additional samples is the delay in receiving the new solenoids from Buckner. At last report, the solenoids were shipped from overseas and had docked in the U.S. We hope to obtain them within one week.

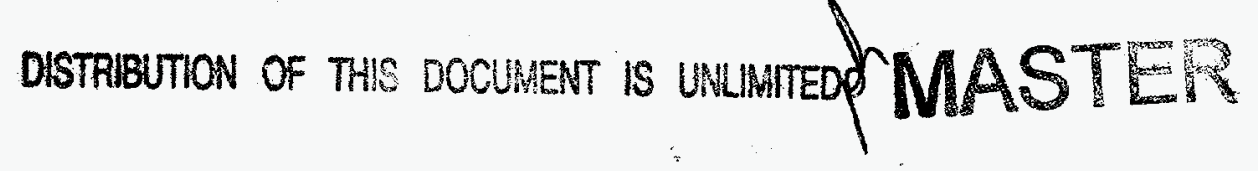




\section{DISCLAIMER}

This report was prepared as an account of work sponsored by an agency of the United States Government. Neither the United States Government nor any agency thereof, nor any of their employees, makes any warranty, express or implied, or assumes any legal liability or responsibility for the accuracy, completeness, or usefulness of any information, apparatus, product, or process disclosed, or represents that its use would not infringe privately owned rights. Reference herein to any specific commercial product, process, or service by trade name, trademark, manufacturer, or otherwise does not necessarily constitute or imply its endorsement, recommendation, or favoring by the United States Government or any agency thereof. The views and opinions of authors expressed herein do not necessarily state or reflect those of the United States Government or any agency thereof. 


\section{DISCLAIMER}

Portions of this document may be illegible electronic image products. Images are produced from the best available original document. 
Mr. Fred L. Hart

June 6, 1998

Page 2

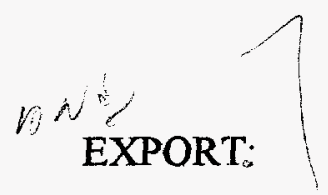

My European representative has traveled extensively to France, Germany, Holland, Italy, and Spain. About 12 European distributors have expressed interest in the product and have requested samples. Once again, as soon as the solenoids are available, these samples will be shipped.

While we are waiting for the solenoids, we are preparing our manufacturing, testing, and quality control procudures. We are also waiting to receive the relays for the Swell. We do however have enough to supply the samples requested. We intend to manufacture 1000 of the swells in the first production run to refine our procedures. We expect to supply several hundred of these as samples for product introduction.

In another development, we have made an agreement to have our products represented in California, Nevada, and Arizona by B \& B Associates. They cover both turf and Ag distributors and have a good reputation with designers of irrigation systems.

Please include this report in our files in accordance with our contractual obligations with the Department Of Energy.

Very Truly Yours,

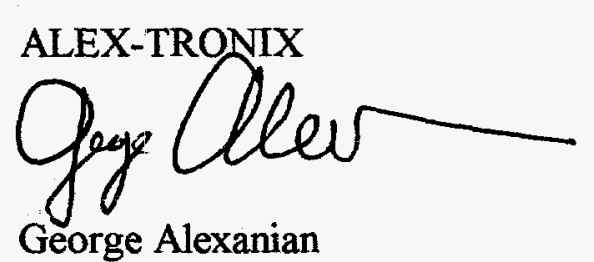

cc: Office of Headquarters, Procurement Services, HR-542

Office of Scientific and Technical Information 